\title{
Protein degradation in the rumen of red clover forage at various stages of growth and conserved as silage or wrapped big bales
}

\author{
Jocelyne Aufrère*, Dominique Graviou, Camille Demarquilly
}

Unité de Recherches sur les Herbivores, Équipe Valeur des Aliments, INRA Clermont-Ferrand Theix, 63122 Saint-Genès-Champanelle, France

(Received 5 March 2002; accepted 6 November 2002)

\begin{abstract}
In order to study the extent to which rumen soluble nitrogen can contribute to the intestinal flow, a study was carried out to simultaneously assess the dynamics of protein disappearance from dacron bags placed in the rumen and the amount of various $\mathrm{N}$ products in the rumen fluid (total nitrogen (tN), ammonia nitrogen (NH3-N), non-ammonia nitrogen (NAN)). The measurements were carried out on 4 sheep fed successively various red clover forages. These forages included the initial growth of fresh red clover (50\% bud, first flower, and full flower). In addition, one silage and one wrapped big bale at the first flower stage and two wrapped big bales (harvested at $51 \%$ and $71 \%$ dry matter) at the full flower stage were given. The effective degradability of nitrogen (DegN) for a fresh forage estimated from the nylon bag procedure did not vary $(p>0.05)$ with the vegetation stage ( 0.727 for the bud stage, 0.694 at the first flower, 0.706 at the full flower). The DegN of the silage was higher $(p<0.05 ; 0.735)$ and the DegN of the wrapped big bale was markedly lower $(p<0.05$; 0.660 ), than the original fresh forage at the first flower. The DegN of the wrapped big bales made at 51 and $71 \%$ DM, respectively, were 0.625 and 0.604 against 0.706 for fresh forage at the full flower stage. The concentrations of $\mathrm{tN}$ and NAN in the rumen fluid were low, highest $1 \mathrm{~h}$ to $2 \mathrm{~h}$ after feeding, and then decreasing up to $7 \mathrm{~h}$ after feeding whatever the growth stage and conservation mode. A part of the solubilised nitrogen remained as protein $1 \mathrm{~h}$ after feeding for fresh red clover harvested at various growth stages, while minimal protein could be seen in the rumen fluid after the sheep were fed silage or wrapped big bales. The part of NAN escaping rumen degradation and transiting with the rumen fluid was between 7 and 13\% of the nitrogen disappearing from the nylon bags (NAN/CP $\times$ $\mathrm{DegN}$ ) placed in the rumen. There was only a small difference for forages at different stages of growth, or modes of conservation. This fraction was higher for wrapped big bales and particularly for the late stage forage (wrapped big bale, $71 \% \mathrm{DM}$, harvested at the full flower stage).

red clover / vegetation stage / conservation method / protein degradation / rumen fluid composition
\end{abstract}

\footnotetext{
* Correspondence and reprints

E-mail: aufrere@clermont.inra.fr
} 


\section{INTRODUCTION}

The protein value of feeds for ruminants is based on an estimation of the quantity of dietary and microbial protein absorbed in the small intestine. Dietary nitrogen that escapes degradation in the rumen is therefore an important factor in determining the protein value.

Previous experiments have demonstrated the effect of the growth stage and conservation method of lucerne (Medicago sativa) [6], cocksfoot (Dactylis glomerata) and perennial ryegrass (Lolium perenne) (unpublished results) on protein degradation in the rumen. The present study was designed to investigate the effects of the growth stage and various methods of conservation (silage and wrapped big bales) on the ruminal in situ degradation of nitrogen (DegN) for red clover. A second objective was to establish whether a portion of the solubilised nitrogen would remain in the rumen long enough as proteins, peptides or amino acids, to escape ruminal degradation by transiting with the liquids.

\section{MATERIAL AND METHODS}

\subsection{Forages}

The experiments were conducted during the 2000 crop year on fresh 'merviot' red clover cut at three different stages of growth (50\% bud, first flower and full flower) during the first harvest cycle. The research site was at INRA Clermont-Ferrand Theix, 63122 Saint-Genès-Champanelle, at an altitude of $800 \mathrm{~m}$ on a deep silt loam soil. Fertilisation was applied in two applications for $\mathrm{P}$ and three applications for $\mathrm{K}$. The application rates were respectively 137 and $237 \mathrm{~kg} \cdot \mathrm{ha}^{-1}$ in June 1999 and March 2000. There was no application of herbicides.

The fresh forage (first flower stage) was cut with a 'KUHN' mower conditioner (Type FC 302 GV, impasse des fabriques, 67700 Saverne). One silage (without wilt- ing) was made from the fresh red clover cut at the first flower. The fresh forage was ensiled at $19 \%$ dry matter in $4-\mathrm{m}^{3}$ experimental silos. Formic acid $\left(5 \mathrm{~L} \cdot \mathrm{t}^{-1}\right)$ was applied at ensiling. The remaining forage was wilted for two days after cutting and one wrapped big bale (64\% dry matter) was made from the forage with a fixed-chamber baler (WELGER, RP 200, Type 1721, Kverneland, Blanchot, avenue de l'Europe, 02402 Château-Thierry Cedex). In addition, two wrapped big bales harvested at respectively $51 \%$ and $71 \%$ dry matter were made from red clover cut at the full flower. The forage was wilted for two days after cutting for the wrapped big bale harvested at $51 \%$ dry matter, and for 3 days for the wrapped big bale harvested at $71 \%$ dry matter.

\subsection{Animals and experimental design}

The study was carried out on four Texel sheep weighing $60 \pm 3 \mathrm{~kg}$ and fitted with a ruminal cannula. During the experimental periods, the animals were housed in individual pens and allowed free access to water and a salt block.

The animals were given fresh or conserved forage in a chopped form. They were fed ad libitum (10\% refusal) at $09.00 \mathrm{~h}$ and $17.00 \mathrm{~h}$ each day.

Two series of measurements were conducted. The first measurements occurred during the spring with the initial growth of the forage harvested at $50 \%$ bud, first flower and full flower. These evaluations were conducted during 2000 in May, early June and late June, respectively. The second set of evaluations were conducted during the autumn with conserved forages (silage with an additive, and wrapped big bales harvested at different stages of growth and with different dry matter contents for the initial growth).

Each measurement period included a 2-wk adaptation phase and 2 weeks of measurements. Ruminal fluid and conduct ruminal content measurements were 
performed the first week. Ruminal in situ degradation kinetics were measured on the second week. Forages placed in the Dacron bags were identical to those as in the diet. The bags were filled at the end of the week of serial sampling and rapidly frozen to avoid modifications of the forages (see Section 2.3).

Concurrently, the digestibility of organic matter (OMD) was measured on another group of 6 intact sheep, 3 or 4 years old, kept in metabolism crates. Digestibility was measured according to the method described by Demarquilly and Weiss [16]. The sheep were fed $10 \%$ above the previous day's consumption, in equal portions at 08.00 and $17.00 \mathrm{~h}$, and the uneaten forage was removed before the morning allocation. Digestibility measurements were done with total collection of the faeces for 6 days after a preliminary period of 15 days. The experiment was conducted on fresh forages and not on frozen forages because freezing at $-20{ }^{\circ} \mathrm{C}$ modifies the characteristics of the forages and their degradability [25, 32].

\subsection{In situ degradation}

Nitrogen degradability was measured using the nylon bag procedure, as described by Michalet-Doreau et al. [37]. Dacron bags (pore size 30-60 $\mu \mathrm{m}$; Ankom Co., Fairport, New York) with an internal surface of $5 \times$ $11 \mathrm{~cm}$ were closed by two stitches. Forage samples weighed into the bags were prepared according to Dulphy et al. [19]. Fresh forages, silages and wrapped big bales were cut into particle sizes of 4-5 mm long. A quantity equivalent to $2.5 \mathrm{~g}$ dry matter (DM) was weighed into the bags and were then incubated in the rumen of the four-fistulated sheep fed the same forage as in the bag. Incubation periods were 2, 4, 8, 16, 24 and $48 \mathrm{~h}$. Two replications per sheep were used for 2, 4 and $8 \mathrm{~h}$ whereas three replications were used for 16, 24 and $48 \mathrm{~h}$. Since it was not possible to insert all the bags at once in the rumens, most of the bags were inserted at $\mathrm{T} 0 \mathrm{~h}$ except for $\mathrm{T} 16 \mathrm{~h}$ and $24 \mathrm{~h}$. The bags
( T $16 \mathrm{~h}$ ) were introduced at $\mathrm{T} 8 \mathrm{~h}$ on the first day and removed on the second day (T $24 \mathrm{~h}$ ) after $16 \mathrm{~h}$ of incubation whereas the bags ( $\mathrm{T} 24 \mathrm{~h}$ ) were introduced on the second day and withdrawn on the third day according to Michalet-Doreau et al. [37]. A standard hay was incubated daily $(8 \mathrm{~h})$ in duplicate in the rumen of each of the animals used, in order to detect any changes in the level of degradation during the experiment. After the removal of the bags from the rumen, they were kept at $-20{ }^{\circ} \mathrm{C}$ until analysis. Prior to analysis, the bags were defrosted and then rinsed with cold water until the rinse water ran clear. The bags were then beaten for $7 \mathrm{~min}$ in a "stomacher" [35], followed by further washing and finally dried at $60{ }^{\circ} \mathrm{C}$ for $48 \mathrm{~h}$. Michalet-Doreau and Ould-Bah [38] showed that beating the residues in the bags in a stomacher can significantly reduce microbial contamination of the undegraded fraction of the sample. Nitrogen solubility was determined without incubation in the rumen ( $\mathrm{T} 0 \mathrm{~h}$ ) by soaking the bags containing the samples in warm water $\left(40^{\circ} \mathrm{C}\right)$ for $1 \mathrm{~h} 30 \mathrm{~min}$, followed by drying as before.

\subsection{Ruminal fluid sampling}

Rumen fluid was taken from the same sheep on two consecutive days, before the morning meal ( $\mathrm{T} 0 \mathrm{~h}$ ), and 1, 2, 4 and $7 \mathrm{~h}$ after feeding. About $150 \mathrm{~mL}$ of the rumen fluid was taken, muslin-filtered, and then centrifuged for $5 \mathrm{~min}$ at $120 \mathrm{~g}$ to remove dietary particles and protozoa. The supernatant was centrifuged at $+4{ }^{\circ} \mathrm{C}$ and $27000 \mathrm{~g}$ for $20 \mathrm{~min}$ in order to remove dietary particles and bacteria [46]. The proteins were then precipitated by adding sulfosalicylic acid $\left(400 \mathrm{~g} \cdot \mathrm{L}^{-1}\right.$ and separated after centrifuging $(20000 \mathrm{~g}$ for $10 \mathrm{~min}$ ).

\subsection{Rumen content and digesta kinetics}

Total reticulo-rumen contents were determined by manually evacuating the rumen 
before the morning meal ( $08 \mathrm{~h} 30)$ and after the evening meal (19 h 00). Manual evacuations of the whole rumen contents were carried out after an interval of at least $60 \mathrm{~h}$ to ensure normal digestion [1].

After emptying, the rumen contents were weighed, homogenised and sampled for DM determination and then reintroduced into the rumen. The total procedure did not exceed $30 \mathrm{~min}$ [7].

A $200 \mathrm{~mL}$ dose of a Cr-EDTA solution [8] was introduced intraruminaly at $6 \mathrm{~h} 30$ ( $2 \mathrm{~h}$ before the morning feeding). Seven samples $(50 \mathrm{~mL})$ were taken $2,4,6,10,26$, $28 \mathrm{~h}$ and $30 \mathrm{~h}$ after administration of the marker to determine the liquid passage rate. The samples were stored at $-20{ }^{\circ} \mathrm{C}$ until $\mathrm{Cr}$ concentration analysis. The concentrations of $\mathrm{Cr}$ were determined by absorption spectrometry using a Perkin-Elmer Model, 2380 spectrophotometer. The Cr-EDTA disappearance in the rumen was fitted using a non-linear regression procedure:

$$
C=C o \cdot \mathrm{e}^{-k t}
$$

where $C$ o is the initial concentration, $C$ the concentration at time $t, t$ the time (h) after infusion of the first sample, and $k$ the fractional turnover rate [26]. The fractional turnover rate was calculated from the slope of linear regression of the natural logarithm of Cr-EDTA concentrations in the rumen fluid [48].

\subsection{Chemical analyses}

The total nitrogen $(\mathrm{tN})$ content of the forages, bag residues, and soluble nitrogen content of the rumen fluids (before and after precipitation with sulfosalicylic acid) were determined using the Kjeldahl method [3]. The protein content of the rumen fluid was determined as the difference between total nitrogen in the rumen fluid before and after precipitation. The NH3-N values were determined on the acid supernatant (after precipitation with sulfosalicylic acid) by the Conway method [15].
The fibre contents of neutral detergent fibre (NDF), acid detergent fibre (ADF) and acid detergent lignin (ADL) were determined for the forages by the method of Goering and Van Soest [21].

The fermentation characteristics were determined in a liquid pressed from the silage, and in an extract from the wrapped big bales after maceration overnight at $4{ }^{\circ} \mathrm{C}$ according to Dulphy and Demarquilly [18]. The soluble nitrogen content was determined by the Kjeldahl method, the NH3-N content by the method of Conway [15], and the lactic acid content by the enzymatic method of Noll [40]. Alcohol and volatile fatty acid contents were determined by gas liquid chromatography [28].

\subsection{Estimation of NAN flow (Tab. VI)}

The fraction of NAN in the rumen fluid that escaped degradation in the rumen and reached the small intestine, was estimated. From our results of NAN content at the different kinetic times $(0 \mathrm{~h}, 1 \mathrm{~h}, 2 \mathrm{~h}, 4 \mathrm{~h}, 7 \mathrm{~h})$, the NAN flow was calculated as the area under the curve, extended to $12 \mathrm{~h}$ and then multiplied by 2 to include the evening meal [6]. The volume of the liquid phase of the rumen was calculated as described in Section 2.5. The fractional passage of the liquid phase was determined from the measurements carried out with chromium-EDTA. The nitrogen degradability (DegN) was measured using dacron bags (see Sect. 2.3). NAN flow (expressed in $\mathrm{g}$ of CP) was the ratio between the NAN content in the rumen $(\mathrm{NAN} \times \mathrm{Vol}$ of the liquid phase $\times \mathrm{kl})$ and the daily dry matter intake (DMI $\left.\left(\mathrm{kg} \cdot \mathrm{d}^{-1}\right)\right)$. This fraction of NAN that flowed out of the rumen in the liquid phase was able to contribute to the undegraded crude protein which escaped degradation in the rumen. It was assumed to be (NAN flow + $(1-$ DegN) $\times \mathrm{CP})$. In order to estimate its importance, NAN was expressed relative to the crude protein fraction degraded in the rumen. $(\mathrm{NAN} / \mathrm{CP} \times \operatorname{DegN})$. 


\subsection{Calculations and statistical analysis}

The in situ dry matter and $\mathrm{N}$ disappearances of red clover forages were fitted to the model of $\varnothing$ rskov and McDonald [41] using a non-linear regression procedure [41]: $\% \mathrm{~N}$ degraded $=\mathrm{a}+\mathrm{b}\left(1-\exp ^{-c t}\right)$ which supposes three $\mathrm{N}$ fractions in the feed: a rapidly degradable one (a), one with a slower degradation (b) at an exponential reducing rate $\left(\exp ^{-c t}\right)$ and one undegradable fraction $(100-a-b)$.

The effective degradability of nitrogen DegN was calculated as:

$$
\begin{aligned}
\operatorname{DegN}= & a+(b \times c) /(c+k p)[33] \\
& \text { assuming kp }=0.06 h^{-1}[44] .
\end{aligned}
$$

The same model was used to calculate the effective degradability of dry matter (DegDM).

The analysis of variance was conducted for various degradation parameters for the nylon bags using the GLM procedure of SAS [43]. The following model was used:

$$
\mathrm{Y}=\mathrm{M}+\mathrm{Ai}+\mathrm{Tj}+\mathrm{Eij}
$$

in which $\mathrm{M}$ is the overall mean; $\mathrm{Ai}$ is the effect of the animal $(d f=3), \mathrm{Tj}$ is the forage treatment, Eij is the error term $(d f=6)$.

There was no significant difference between the rumen fluid parameters $(\mathrm{tN}$, NH3-N, NAN) on the two measurement days (Duncan test) [43]. Therefore, the mean value of the two measurement days was analysed by the same model.

For the whole parameters (DegDM, DegN, and rumen fluid composition), the fresh forages were compared on the basis of their vegetative stage (first flower) and also on the basis of the vegetation stage (first flower or full flower) within their mode of conservation (silage or wrapped big bales).

The results of these comparisons were reported in Tables III, IV and V, and in Figures 1, 2 and 3.

\section{RESULTS}

\subsection{Chemical composition (Tabs. I and II)}

The crude protein content decreased according to the maturity of the plant. It was lower for wrapped big bales than for fresh forage cut at the same stage. Concurrently, the fibre content of the fresh red clover forage (NDF and ADF) increased with the maturity of the plant and was the highest for the wrapped big bales.

The organic matter digestibility (OMD) was higher and decreased with the maturity of the forage. Furthermore, it was higher for the fresh forages and lower for the silage and wrapped big bales.

The direct cut silage was of very good quality: lactic acid fermentation dominated in the fermentative process (Tab. II). For wrapped big bales, the production of lactic acid was restricted, as compared to silage, especially in the wrapped big bales harvested at $71 \% \mathrm{DM}$.

\subsection{In situ degradation}

The degradability of dry matter decreased progressively with the maturity of the plant $(p>0.05)$, while DegN did not vary with plant maturity ( $p>0.05$; Tab. III). At the first flower (Tab. IV), DegDM for the silage and wrapped big bales were lower $(p<0.05)$ than those of the fresh forages harvested at the same stage of growth. The DegN of the silage conserved with formic acid was higher $(p<0.05)$ than that of the fresh forage, while the DegN of the wrapped big bale was lower $(p<0.05)$ than that of the fresh forage.

At the full flower stage (Tab. V), Deg $\mathrm{DM}$ and DegN of the wrapped big bales were lower than those of the fresh forages $(p<0.05)$. Although the DegN and the ' $\mathrm{b}$ ' and ' $c$ ' degradability parameters were not significantly different for the wrapped big 


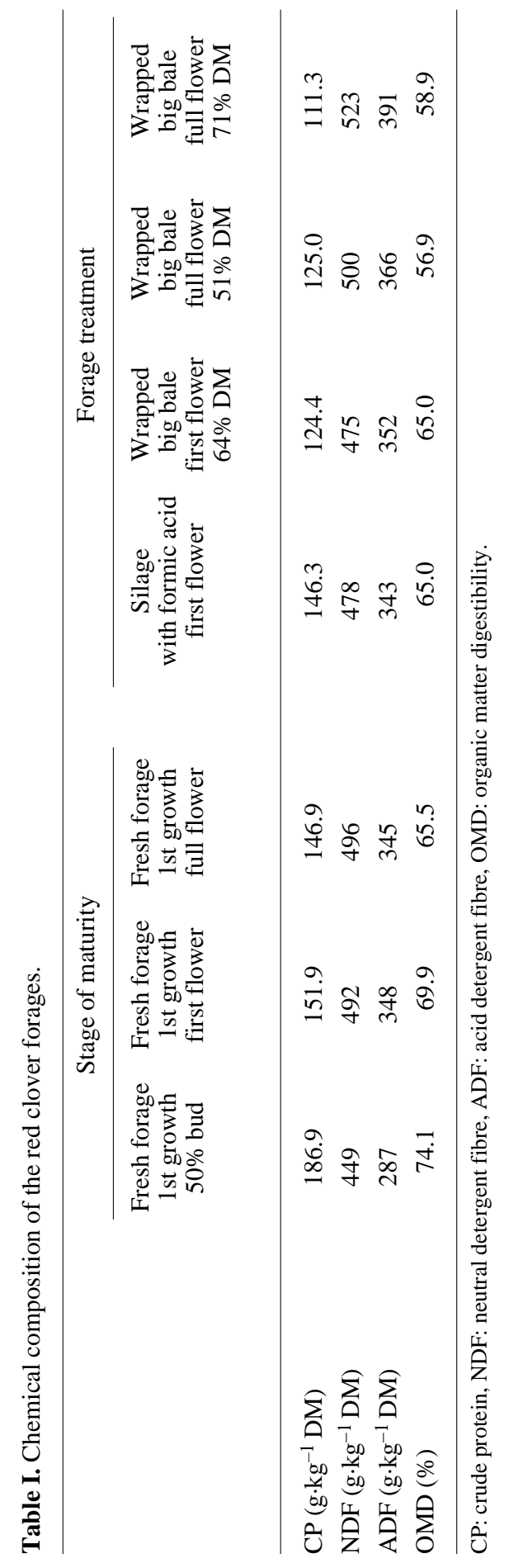


bales harvested at different dry matter contents, the 'a' fraction and 'c' degradation rate decreased for the wrapped big bale harvested at the highest dry matter.
At the first and full flower, the DegN of the wrapped big bales were lower $(p<0.05)$ than silage and fresh forages harvested at the corresponding stage.

Table II. Fermentation characteristics of the silage and wrapped big bales of red clover forages.

\begin{tabular}{|c|c|c|c|c|}
\hline & \multicolumn{4}{|c|}{ Forage treatment } \\
\hline & $\begin{array}{l}\text { Silage with } \\
\text { formic acid } \\
\text { first flower } \\
19 \% \text { DM }\end{array}$ & $\begin{array}{l}\text { Wrapped } \\
\text { big bale } \\
\text { first flower } \\
64 \% \text { DM }\end{array}$ & $\begin{array}{l}\text { Wrapped } \\
\text { big bale } \\
\text { full flower } \\
51 \% \text { DM }\end{array}$ & $\begin{array}{l}\text { Wrappe } \\
\text { big bale } \\
\text { full flower } \\
71 \% \text { DM }\end{array}$ \\
\hline $\mathrm{pH}$ & 3.97 & 5.11 & 4.70 & 5.45 \\
\hline NH3-N $(\% \mathrm{Nt})$ & 7.5 & 8.7 & 7.4 & 6.1 \\
\hline Sol N (\%tN) & 37.7 & 49.6 & 36.2 & 34.9 \\
\hline \multicolumn{5}{|c|}{ Acids $\left(\mathrm{g} \cdot \mathrm{kg}^{-1} \mathrm{DM}\right)$} \\
\hline Lactic & 69.4 & 24.3 & 48.9 & 8.5 \\
\hline Acetic & 23.6 & 3.6 & 6.4 & 2.0 \\
\hline Propionic & 0.7 & 1.0 & 1.4 & 1.0 \\
\hline Butyric & 0.2 & 0.8 & 0.7 & 0.1 \\
\hline \multicolumn{5}{|c|}{ Alcohols $\left(\mathrm{g} \cdot \mathrm{kg}^{-1} \mathrm{DM}\right)$} \\
\hline Methanol & 1.1 & 0 & 0 & 0.2 \\
\hline Ethanol & 2.3 & 0.6 & 1.0 & 0.2 \\
\hline Propanol & 0.3 & 1.0 & 0 & 0 \\
\hline Butanol & 0.3 & 0.8 & 0.8 & 0.6 \\
\hline
\end{tabular}

Table III. In situ degradation parameters for red clover forages according to the stage of growth.

\begin{tabular}{ccccc}
\hline & $\begin{array}{c}\text { Fresh forage } \\
\text { 1st growth } \\
50 \% \text { bud }\end{array}$ & $\begin{array}{c}\text { Fresh forage } \\
\text { 1st growth } \\
\text { first flower }\end{array}$ & $\begin{array}{c}\text { Fresh forage } \\
\text { 1st growth } \\
\text { full flower }\end{array}$ & RSD \\
\hline $\mathrm{DM}$ & & & & \\
$\mathrm{a}$ & $0.240^{\mathrm{b}}$ & $0.257^{\mathrm{b}}$ & $0.284^{\mathrm{a}}$ & 0.0124 \\
$\mathrm{~b}$ & $0.559^{\mathrm{a}}$ & $0.431^{\mathrm{b}}$ & $0.480^{\mathrm{ab}}$ & 0.0704 \\
$\mathrm{c}$ & 0.155 & 0.203 & 0.079 & 0.0704 \\
$\mathrm{DegDM}$ & $0.607^{\mathrm{a}}$ & $0.588^{\mathrm{ab}}$ & $0.550^{\mathrm{b}}$ & 0.0022 \\
$\mathrm{~N}$ & & & & 0.0049 \\
$\mathrm{a}$ & $0.238^{\mathrm{c}}$ & $0.249^{\mathrm{b}}$ & $0.370^{\mathrm{a}}$ & 0.0421 \\
$\mathrm{~b}$ & $0.593^{\mathrm{a}}$ & $0.532^{\mathrm{ab}}$ & $0.495^{\mathrm{b}}$ & 0.1062 \\
$\mathrm{c}$ & $0.307^{\mathrm{ab}}$ & $0.355^{\mathrm{a}}$ & $0.134^{\mathrm{b}}$ & 0.0250 \\
\hline DegN & 0.727 & 0.694 & 0.706 & \\
\hline
\end{tabular}

DM: dry matter, N: nitrogen, a: rapidly degraded fraction, b: slowly degraded fraction, c: rate of degradation $\left(\mathrm{h}^{-1}\right)$, Deg: degradability $\left.=\mathrm{a}+(\mathrm{bc}) /(\mathrm{c}+\mathrm{k})\right)$, RSD: residual standard deviation; differents superscripts in a same line correspond to a significant difference $(p<0.05)$. 
Table IV. In situ degradation parameters for red clover according to the conservation method (silage or wrapped big bale) at the first flower stage.

\begin{tabular}{ccccc}
\hline & $\begin{array}{c}\text { Fresh forage } \\
\text { 1st growth } \\
\text { first flower }\end{array}$ & $\begin{array}{c}\text { Silage } \\
\text { first flower } \\
\text { formic acid } \\
19 \% \text { DM }\end{array}$ & $\begin{array}{c}\text { Wrapped } \\
\text { big bale } \\
\text { first flower } \\
64 \% \text { DM }\end{array}$ & RSD \\
\hline DM & $0.257^{\mathrm{b}}$ & $0.331^{\mathrm{a}}$ & $0.331^{\mathrm{a}}$ & 0.0092 \\
$\mathrm{a}$ & 0.431 & $0.394^{\mathrm{a}}$ & 0.451 & 0.0073 \\
$\mathrm{~b}$ & $0.203^{\mathrm{a}}$ & $0.075^{\mathrm{b}}$ & $0.0476^{\mathrm{b}}$ & 0.0126 \\
$\mathrm{c}$ & $0.588^{\mathrm{a}}$ & $0.550^{\mathrm{b}}$ & $0.519^{\mathrm{c}}$ & 0.0053 \\
DegDM & $0.249^{\mathrm{b}}$ & $0.421^{\mathrm{a}}$ & $0.407^{\mathrm{a}}$ & 0.0117 \\
$\mathrm{~N}$ & $0.532^{\mathrm{a}}$ & $0.410^{\mathrm{b}}$ & $0.472^{\mathrm{ab}}$ & 0.0460 \\
$\mathrm{a}$ & $0.355^{\mathrm{a}}$ & $0.223^{\mathrm{ab}}$ & $0.0745^{\mathrm{b}}$ & 0.1099 \\
$\mathrm{~b}$ & $0.694^{\mathrm{b}}$ & $0.735^{\mathrm{a}}$ & $0.660^{\mathrm{c}}$ & 0.0145 \\
$\mathrm{c}$ & & & & \\
DegN & & & &
\end{tabular}

DM: dry matter, $\mathrm{N}$ : nitrogen, a: rapidly degraded fraction, b: slowly degraded fraction, c: rate of degradation $\left(\mathrm{h}^{-1}\right)$, Deg: degradability $\left.=\mathrm{a}+(\mathrm{bc}) /(\mathrm{c}+\mathrm{k})\right)$, RSD: residual standard deviation; different superscripts in a same line correspond to a significant difference $(p<0.05)$.

Table V. In situ degradation parameters for red clover according to the conservation method (wrapped big bales) at the full flower stage.

\begin{tabular}{ccccc}
\hline & $\begin{array}{c}\text { Fresh forage } \\
\text { 1st growth } \\
\text { first flower }\end{array}$ & $\begin{array}{c}\text { Wrapped } \\
\text { big bale } \\
\text { full flower } \\
51 \% \mathrm{DM}\end{array}$ & $\begin{array}{c}\text { Wrapped } \\
\text { big bale } \\
\text { full flower } \\
71 \% \mathrm{DM}\end{array}$ & RSD \\
\hline $\mathrm{DM}$ & & & & \\
$\mathrm{a}$ & 0.284 & 0.281 & 0.272 & 0.0083 \\
$\mathrm{~b}$ & 0.480 & 0.472 & 0.440 & 0.0967 \\
$\mathrm{c}$ & 0.0790 & 0.0576 & 0.0610 & 0.0383 \\
$\mathrm{DegDM}$ & $0.550^{\mathrm{a}}$ & $0.477^{\mathrm{b}}$ & $0.473^{\mathrm{b}}$ & 0.0325 \\
$\mathrm{~N}$ & & & & \\
$\mathrm{a}$ & $0.370^{\mathrm{a}}$ & $0.364^{\mathrm{a}}$ & $0.343^{\mathrm{b}}$ & 0.0079 \\
$\mathrm{~b}$ & 0.495 & 0.435 & 0.473 & 0.0785 \\
$\mathrm{c}$ & 0.134 & 0.147 & 0.083 & 0.0528 \\
$\mathrm{DegN}$ & $0.706^{\mathrm{a}}$ & $0.625^{\mathrm{b}}$ & $0.604^{\mathrm{b}}$ & 0.0369 \\
\hline
\end{tabular}

DM: dry matter, N: nitrogen, a: rapidly degraded fraction, b: slowly degraded fraction, c: rate of degradation $\left(\mathrm{h}^{-1}\right)$, Deg: degradability $=\mathrm{a}+(\mathrm{bc} /(\mathrm{c}+\mathrm{k}))$, RSD: residual standard deviation; different superscripts in a same line correspond to a significant difference $(p<0.05)$.

\subsection{Rumen fluid composition}

For all fresh forages, whatever their stage of vegetation at harvest or the conservation mode, the $\mathrm{tN}, \mathrm{NH} 3-\mathrm{N}$, protein- $\mathrm{N}$ or NAN content in the rumen fluid was the highest 1 or $2 \mathrm{~h}$ after feeding and then decreased up to $7 \mathrm{~h}$ after feeding (Figs. 1, 2 and 3).

The NAN content is the difference between $\mathrm{tN}$ and $\mathrm{NH} 3-\mathrm{N}$. Non-ammonia $\mathrm{N}$ is made up of peptide $\mathrm{N}$, amino-acid-N and 
protein $\mathrm{N}$. The NAN concentration followed the same pattern over time as the $\mathrm{tN}$ and NH3-N contents.
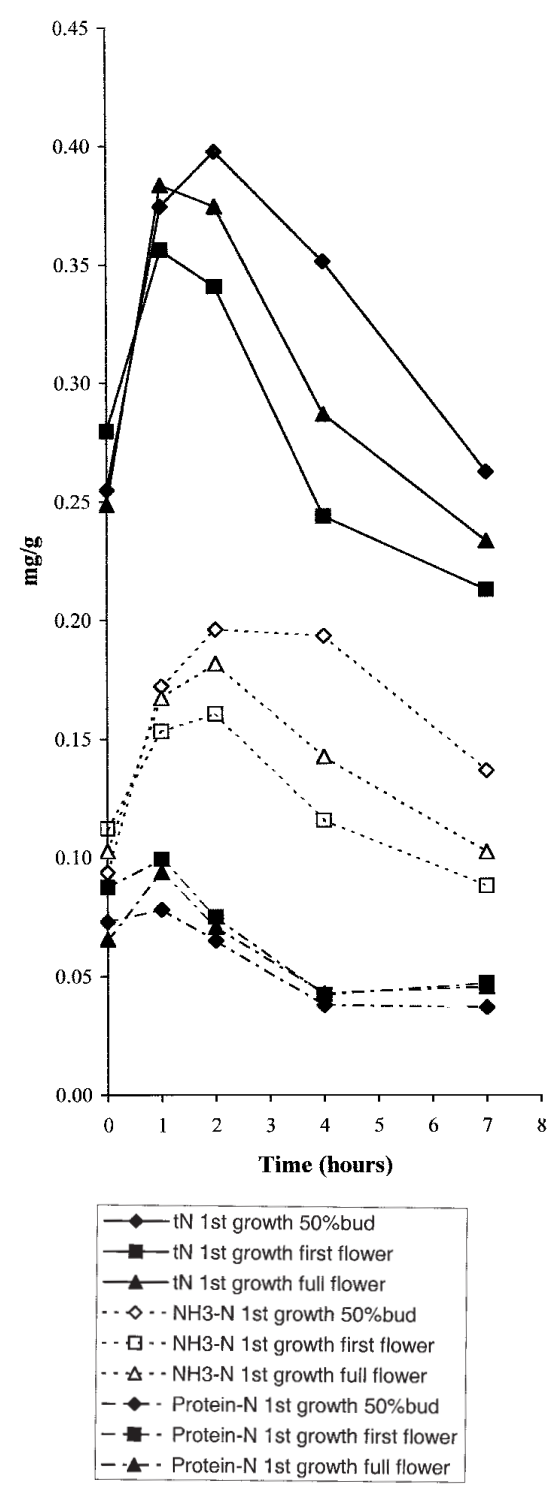

Figure 1. Concentrations $\left(\mathrm{mg} \cdot \mathrm{g}^{-1}\right.$ ) of $\mathrm{tN}, \mathrm{NH} 3-\mathrm{N}$ and protein- $\mathrm{N}$ in the rumen fluid for red clover fresh forages harvested at the 1st growth stage (50\% bud, first flower and full flower), before the morning meal ( $\mathrm{T} 0 \mathrm{~h}$ ) and $1 \mathrm{~h}, 2 \mathrm{~h}, 4 \mathrm{~h}$, and $7 \mathrm{~h}$ after the meal.
For all fresh forages, the $\mathrm{tN}$ content in the rumen fluid decreased with plant maturity $(p>0.05)$ (Fig. 1). In the rumen fluid,
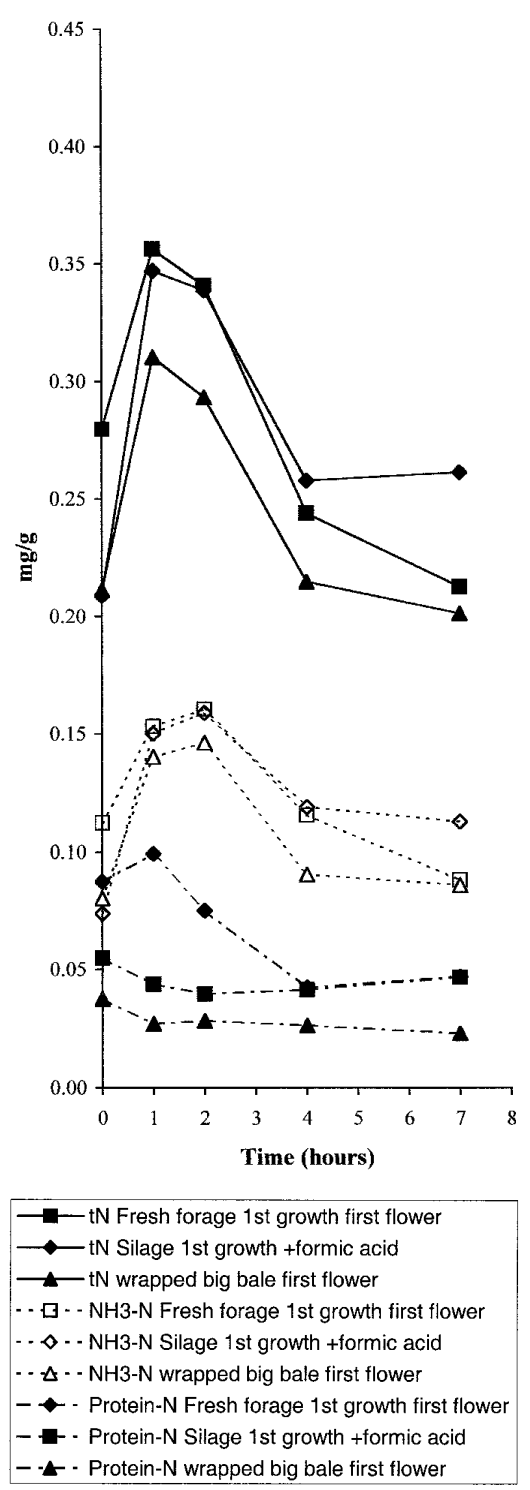

Figure 2. Evolution of the concentrations $\left(\mathrm{mg} \cdot \mathrm{g}^{-1}\right)$ of $\mathrm{tN}, \mathrm{NH} 3-\mathrm{N}$ and protein-N in the rumen fluid for red clover fresh forage harvested at the 1st growth stage (first flower), silage + formic acid and wrapped big bale, before the morning meal (T $0 \mathrm{~h}$ ) and $1 \mathrm{~h}, 2 \mathrm{~h}, 4 \mathrm{~h}$, and $7 \mathrm{~h}$ after the meal. 


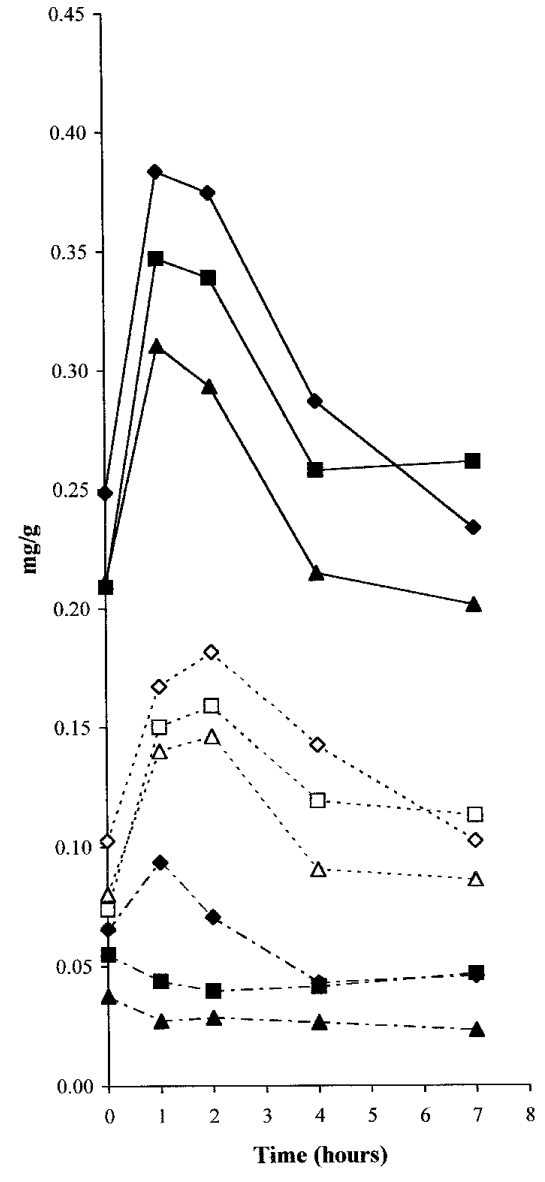

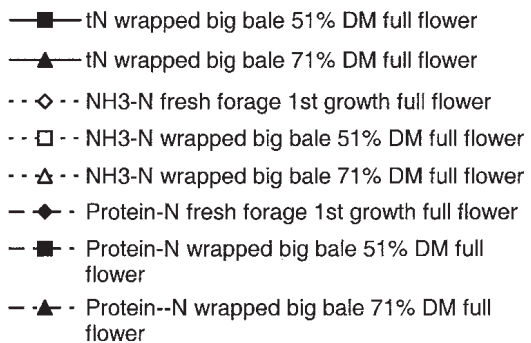

Figure 3. Evolution of the concentrations $\left(\mathrm{mg} \cdot \mathrm{g}^{-1}\right)$ of $\mathrm{tN}, \mathrm{NH} 3-\mathrm{N}$ and protein-N in the rumen fluid for red clover fresh forage harvested at 1st growth stage (full flower) and wrapped big bales the harvested at 51 and $71 \%$ DM, before the morning meal ( $\mathrm{T} 0 \mathrm{~h}$ ) and $1 \mathrm{~h}, 2 \mathrm{~h}, 4 \mathrm{~h}$, and $7 \mathrm{~h}$ after the meal. the mean value of $\mathrm{N}$ constituents were lower than those we obtained for lucerne [6], and comparable to the results for ryegrass and cocksfoot for the different preserving methods (unpublished results). The NH3-N/tN ratio represented about $45 \%, 1$ and $2 \mathrm{~h}$ after feeding, for fresh forages harvested at different growth stages, and for preserved forages as silage and wrapped big bales. It remained higher (> 40\%) until $7 \mathrm{~h}$ after feeding. Although the NH3-N and $\mathrm{tN}$ contents decreased with the vegetation stage for fresh forages and were lower for the conserved forages than for the fresh forages, generally the ratio between $\mathrm{NH} 3-\mathrm{N}$ and $\mathrm{tN}$ did not change.

A part of solubilised nitrogen remained as protein- $\mathrm{N}(24 \%$ to $26 \% \mathrm{tN})$ at $1 \mathrm{~h}$ after feeding for the fresh forages, while minimal protein-N was observed in the rumen fluid of sheep fed silage and wrapped big bales.

\section{DISCUSSION}

At the first flower stage, generally silage and wrapped big bales had lower NDF contents than the corresponding fresh forages. Such differences have been previously observed by Dulphy and Demarquilly (unpublished results): hemi cellulose is partly hydrolysed in the silo [34]. The digestibility of the initial growth of red clover decreased with advancing maturity in an approximately linear fashion; this is typically related to the declining leaf:stem ratio [20, 49]. The digestibility of red clover was lower than that of perennial ryegrass [14], but the rate of decline with age and the consequent stemminess were similar [17]. The reduction in digestibility was related to the increase in the cell-wall constituents [47].

The concentration of crude protein decreases with plant maturity because the leaf proportion decreases while the fibre content increases. Total nitrogen content was lower in the silage and wrapped big bales than in fresh forage as a result of the 
respective losses of nitrogen in the effluent and the losses of leaves at harvesting. Lucerne and red clover nitrogen are generally degraded more extensively in the rumen than grasses [45], but the distribution of morphological components is not the same and these legumes are degraded differently in the rumen. The fraction 'a', degradation rate, and the undegradable fraction were higher for lucerne than for red clover [14]. These authors suggest that the undegradable fraction was considerably larger for lucerne than for red clover due to the heavy lignification of the stem tissue in lucerne. In addition, the ratio of leaf tissue was higher for red clover $(84 \%)$ than for lucerne $(65 \%)$. The data of Coblentz et al. [14] showed that the degradability of lucerne and red clover are similar while in our results [6], red clover was less degraded than lucerne. Nocek and Grant [39], Albrecht and Broderick [2], Le Goffe et al. [30], Hvelplund and Weisberg [27] and Hoffman et al. [23] also reported that red clover has a lower nitrogen degradation than lucerne. In in vitro studies, Messman et al. [36] observed that the disappearance of $\mathrm{N}$ from red clover tended to be less important than that from lucerne during the first $6 \mathrm{~h}$ of incubation, although by $12 \mathrm{~h}$ of incubation by in situ methods, all two forages had similar percentages of remaining $\mathrm{N}$.

The average $\mathrm{tN}$ and NH3-N contents in the rumen tended to decrease with the age of the plant and remained higher for fresh forages than for silages (with formic acid) and wrapped big bales, which were in agreement with other results for silages $[6,13]$. As reported earlier by Lindberg et al. [31], the $\mathrm{tN}$ and NH3-N concentrations in the rumen were low, although the $\mathrm{tN}$ contents of the forages were higher. Ciszuk and Eriksson [13], compared grass and red clover at the same nitrogen content and the same nitrogen intake and observed a lower NH3-N content with red clover than with grass. The results obtained by Broderick et al. [9] showed that the free amino acids released in the lucerne extract were approximately five times greater than those in the red clover extract. Mixing clover and lucerne extracts substantially decreases proteolysis, whereas mixing lucerne extract with boiled clover extract yields a slightly more rapid free amino acid release than lucerne alone [9]. The lower non protein nitrogen that has been found consistently in red clover silage [2, 42], results from the action of polyphenol oxidase. This enzyme system reacts with $\mathrm{O}_{2}$ and phenols normally present in red clover to produce quinones that inhibit the plant proteases that break down forage proteins in the silo $[2,11,22,29,50]$.

The NH3-N content in the rumen fluid is the result of a set of interacting events and can be affected by factors such as the rate and extent of ruminal protein degradation, the amount of fermentable carbohydrates, and the efficiency of the incorporation of degraded $\mathrm{N}$ into microbial cells.

The lower NH3-N concentration measured in the rumen may occur for several reasons:

(1) Red clover OMD contributes to a great utilisation of energy and nitrogen in the rumen. Moreover, soluble carbohydrates exist in a greater concentration in red clover than in lucerne [31]; this will facilitate a better utilisation of nitrogen by the microbial populations.

(2) Dry matter intake and concurrent nitrogen intake was lower for red clover than for lucerne, which is consistent with the results of Broderick et al. [10], Hoffman et al. [24].

(3) The presence of the enzyme polyphenol oxidase, decreased proteolysis and non protein nitrogen content (NPN). Forage NPN consists of oligopeptides, free amino acids, ammonium compounds and other small molecules that rapidly contribute to the ruminal ammonia pool [12].

However, a part of the solubilised nitrogen remained as protein- $\mathrm{N}$ for $1 \mathrm{~h}$ and $2 \mathrm{~h}$ in the rumen after feeding fresh red clover, as we had observed previously $[5,6]$. 
Table VI. Ratio between the amount of non-ammonia nitrogen (NAN) likely to escape degradation in the rumen and degraded protein for red clover according to the vegetation stage or conservation method.

\begin{tabular}{|c|c|c|c|c|c|c|}
\hline & $\begin{array}{l}\mathrm{DMI}^{\mathrm{a}} \\
\left(\mathrm{kg} \cdot \mathrm{d}^{-1}\right)\end{array}$ & $\operatorname{DegN}^{b}$ & $\begin{array}{l}\mathrm{Vol}^{\mathrm{c}} \\
(\mathrm{L})\end{array}$ & $\begin{array}{c}\mathrm{kl}^{\mathrm{d}} \\
\left(\mathrm{h}^{-1}\right)\end{array}$ & $\begin{array}{c}\text { NAN flow }{ }^{\mathrm{e}} \\
\left(\mathrm{CP} \cdot \mathrm{kg}^{-1} \mathrm{DMI} \cdot \mathrm{d}^{-1}\right)\end{array}$ & $\begin{array}{c}\mathrm{NAN} / \mathrm{CP} \times \operatorname{DegN} \\
(\%)\end{array}$ \\
\hline \multicolumn{7}{|l|}{ Fresh forage 1st growth: } \\
\hline $50 \%$ bud & 1.74 & 0.727 & 8.3 & 0.089 & 10 & 7.3 \\
\hline First flower & 1.68 & 0.694 & 9.1 & 0.070 & 8.5 & 8.1 \\
\hline Full Flower & 1.77 & 0.706 & 9.3 & 0.077 & 9.3 & 9.00 \\
\hline \multicolumn{7}{|l|}{ First Flower: } \\
\hline Silage with formic acid & 1.90 & 0.735 & 13.3 & 0.065 & 10.4 & 9.8 \\
\hline Wrapped big bale (64\% DM) & 1.30 & 0.660 & 11.9 & 0.049 & 8.8 & 10.7 \\
\hline \multicolumn{7}{|l|}{ Full Flower: } \\
\hline Wrapped big bale (51\% DM) & 1.48 & 0.625 & 10.5 & 0.062 & 6.9 & 8.9 \\
\hline Wrapped big bale (71\% DM) & 1.53 & 0.604 & 12.6 & 0.053 & 8.6 & 12.8 \\
\hline
\end{tabular}

a DMI: dry matter intake.

${ }^{\mathrm{b}}$ DegN: effective degradability of nitrogen $\left(\mathrm{kp}=0.06 \mathrm{~h}^{-1}\right)$.

c Vol: mean volume of liquid phase (L).

$\mathrm{d} \mathrm{kl}$ : daily digesta fractional turnover rate $\left(\mathrm{h}^{-1}\right)$

${ }^{\mathrm{e}} \mathrm{NAN}$ flow expressed in $\mathrm{g}$.

The fraction of NAN in the rumen fluid that escaped degradation in the rumen and reached the small intestine was estimated (Tab. VI). The present study showed that within a feeding cycle, soluble NAN derived from red clover was only significant during the first hours following the beginning of ingestion. In the French PDI (protein digestible in the intestine) system, the amount of rumen degraded protein is estimated as $[1-1.11 \times(1-\operatorname{DegN})] \times \mathrm{CP}$ [44] The factor 1.11 is a global coefficient to take into account the soluble NAN escaping degradation in the rumen, variation on passage rate, microbial contamination. In the present work ruminal NAN data showed that for red clover the coefficient of 1.11 is not high enough to consider the discrepancy between the observed degraded protein of the forage and its estimation by the nylon bag method. The part of NAN escaping rumen degradation and transiting with the rumen fluid reached an average $9.3 \%$ of the nitrogen disappearing from the nylon bags placed in the rumen $(\mathrm{NAN} / \mathrm{CP} \times \operatorname{DegN})$. This was from 7 to $9 \%$ for fresh forages and from 9 to $13 \%$ for the conserved forages. As in our results with lucerne [6], and in grasses (unpublished results), a part of soluble $\mathrm{N}$ escaped rumen degradation and flowed to the duodenum in the liquid phase of the digesta with the silages and wrapped big bales. This fraction was lower than those of perennial ryegrass and cocksfoot and equal to that of lucerne. As we observed elsewhere [4], the amount of NAN increased with the stage of harvesting; it was higher in more mature forages (the wrapped big bale harvested at the full flower stage with $71 \% \mathrm{DM})$.

\section{CONCLUSION}

The DegN in fresh red clover decreased marginally with the age of the forage. It was higher for silage, but much lower for wrapped big bales cut at the same stage. In the rumen fluid, part of the solubilised nitrogen remained as proteins at $\mathrm{T} 1 \mathrm{~h}$ after the feeding of fresh forages, while minimal protein was observed after feeding in the rumen 
fluid of sheep that consumed silage or wrapped big bales. The part of NAN of the rumen fluid escaping degradation in the rumen was between $7 \%$ and $13 \%$ of the nitrogen disappearing from the nylon bags placed in the rumen.

\section{REFERENCES}

[1] Aitchison E.M., Gill M., Dhanoa M.S., Osbourn D.F., The effect of digestibility and forage species on the removal of digesta from the rumen and the voluntary intake of hay by sheep, $\mathrm{Br}$. J. Nutr. 56 (1986) 463-476.

[2] Albrecht K.A., Muck R.E., Crop quality and utilisation: proteolysis in ensiled forage legumes that vary in tannin concentration, Crop Sci. 31 (1991) 464-469.

[3] AOAC, Official Methods Of Analysis, 13th Ed., Association of Official Analytical Chemists, Washington, DC, 1980 .

[4] Aufrère J., Graviou D., Degradation of proteins in the rumen of fresh forages of legumes and grasses cut at different vegetation stages, Congrès EGF, La Rochelle, 27-31 May 2002.

[5] Aufrère J., Boulberhane D., Graviou D., Andrieu J.P., Demarquilly C., Characterisation of in situ degradation of lucerne proteins according to forage type (green forage, hay and silage) using gel electrophoresis, Anim. Feed Sci. Technol. 50 (1994) 75-85.

[6] Aufrère J., Graviou D., Baumont R., Detour A., Demarquilly C., Degradation in the rumen of proteins from fresh lucerne forage in various stages of growth and conserved as silage or hay, Ann. Zootech. 49 (2000) 461-474

[7] Baumont R., Jailler M., Dulphy J.P., Dynamic of voluntary intake, feeding behaviour and rumen function in sheep fed three contrasting types of hay, Ann. Zootech. 46 (1997) 231-244.

[8] Binnerts W.T., Van't Klooster A.T., Frens A.M., Soluble chromium indicator measured by automatic absorption in digestion experiments, Vet. Rech. 82 (1968) 470.

[9] Broderick G.A,. Desirable characteristics of forage legumes for improving protein utilization in ruminants, J. Anim. Sci. 73 (1995) 2760-2773

[10] Broderick G.A., Walgenbach R.P., Sterrenburg E., Performance of lactating dairy cows fed alfalfa or red clover silage as the sole forage, J. Dairy Sci. 83 (2000) 1543-1551.

[11] Broderick G.A., Walgenbach R.P., Maignan S. Production of lactating cows fed alfalfa or red clover silage at equal dry matter or crude protein contents in the diet, J. Dairy Sci. 84 (2001) $1728-1737$.
[12] Choi C.W., Ahvenjärvi S., Vanhatalo A Toivonen V., Huhtanen P., Quantitation of the flow of soluble non-ammonia nitrogen entering the omasal canal of dairy cows fed grass silage based diets, Anim. Feed Sci. Technol. 96 (2002) 203-220.

[13] Ciszuk P., Eriksson S., Ammonia formation in the rumen of sheep fed on grass, clover or lucerne preserved in various ways, Swedish J. Agric. Res. 3 (1973) 13-20.

[14] Coblentz W.K., Fritz J.O., Fick W.H., Cochran R.C., Shirley J.E., In situ dry matter, nitrogen and fiber degradation of alfalfa, red clover and eastern gamagrass at four maturities, J. Dairy Sci. 81 (1998) 150-161.

[15] Conway E.J., Microdiffusion analysis and volumetric analysis error. Crosby Lockwood and Son, London, 1957.

[16] Demarquilly C., Prévision de la Valeur Nutritive des Aliments des Ruminants, INRA, Centre de Recherches Zootechniques et Vétérinaires de Theix, Beaumont, 1981.

[17] Demarquilly C., Weiss., Tableaux de la valeur alimentaire des fourrages vert, Étude S.E.I. $\mathrm{n}^{\circ}$ 42, Versailles, INRA, 1970.

[18] Dulphy J.P., Demarquilly C., Problèmes particuliers aux ensilages. Prévision de la valeur nutritive des aliments des Ruminants, INRA, Publ., 1981, pp. 81-104.

[19] Dulphy J.P., Demarquilly C., Baumont R., Jailler M., L'Hotelier L., Dragomir C., Study of modes of preparation of fresh and conserved forages for measurement of their dry matter and nitrogen degradations in the rumen, Ann. Zootech. 48 (1999) 275-287.

[20] Frame J., Charlton J.F.L., Laidlaw A.S., Red clover, Chap. 4 in: Temperate Forage Legumes, CAB international 1998, pp. 181-224.

[21] Goering H.K, Van Soest P.J., Forage fiber analyses, in: Agricultural Handbook no. 379, US Department of Agriculture, Washington, DC, 1970, pp. 1-20.

[22] Hatfield R., Muck R., Characterizing proteolytic inhibition in red clover silage, in: Thomas Pauly (Ed.), The XIIth International Silage Conference. Silage production in relation to animal performance, animal health, meat and milk quality, July 5-7, Uppsala, Sweden, 1999, pp. 147-148.

[23] Hoffman P.C., Sievert S.J., Shaver R.D., Welch D.A., Combs D.K., In situ dry matter, protein, and fiber degradation of perennial forages, J. Dairy Sci. 76 (1993) 2632-2643.

[24] Hoffman P.C., Combs D.K., Brehm N.M. Welch D.A., Performance of lactating dairy cows fed red clover or alfalfa silage, J. Dairy Sci. 80 (1997) 3308-3315.

[25] Hristov A.N., Nitrogen fractions and in sacco dry matter and crude protein degradability of fresh and frozen alfalfa, Anim. Feed Sci. Technol. 71 (1998) 351-355. 
[26] Huhtanen P., Kukkonen U., Comparison of methods, markers, sampling sites and models for estimating digesta passage kinetics in cattle fed at two levels of intake, Anim. Feed Sci. Technol. 52 (1995) 141-158.

[27] Hvelplund T., Weisbjerg M.R., In situ techniques for the estimation of protein degradability and postrumen availability, in: Givens D.I. Owen E., Axford R.F.E., Omed H.M. (Eds.), Forage Evaluation in Ruminant Nutrition, 1999, pp. 215-258

[28] Jouany J.P., Dosage des acides gras volatils et des alcools dans les ensilages par chromatographie en phase gazeuse, Bull. Tech. CRZV Theix INRA 46 (1981) 63-66.

[29] Jones B.A., Hatfield R.D., Muck R.E., Inhibition of proteolysis by red clover, in: O'Kiely P. O’Connell M., Murphy J. (Eds.), Proc. X Int. Silage Conf., Dublin, 1993, pp. 106-107.

[30] Le Goffe P., Vérité R., Peyraud J.L., Influence de l'espèce et de la saison sur la dégradabilité de l'azote des fourrages verts dans le rumen, Ann Zootech. 42 (1993) 3-15.

[31] Lindberg J.E., Clason C., Ciszuk P., Den Braver E., Buffer-soluble and short-term in sacco degradable crude protein in relation to ruminal ammonia concentration in sheep, Swedish J. Agric. Res. 12 (1982) 77-82.

[32] MacRae J.C., Campbell D.R., Eadie J., Changes in the biochemical composition of herbage upon freezing and thawing, J. Agric. Sci. Camb. 84 (1975) 125-131.

[33] Mc Donald I., A revised model for the estimation of protein degradability in the rumen, J. Agric. Sci. 96 (1981) 251-252.

[34] Mc Donald P., Henderson N., Heron S., The Biochemistry of Silage, Chalcombe publications, 1991, pp. 340.

[35] Merry R. J., Mc Allan R.B., A comparison of the chemical composition of mixed bacteria harvested from the liquid and solid fractions of rumen digesta, Br. J. Nutr. 50 (1983) 701-709.

[36] Messman M.A., Weiss W.P., Albrecht K.A., In situ disappearance of individual proteins and nitrogen from legume forages containing varying amount of tannins, J. Dairy Sci. 79 (1996) 1430-1435.

[37] Michalet-Doreau B., Vérité R., Chapoutot P. Méthodologie de mesure de la dégradabilité in sacco de l'azote des aliments dans le rumen, Bull. Tech. CRZV Theix 69 (1987) 5-7.

[38] Michalet-Doreau B., Ould-Bah M.Y., Estimation of the extent of bacterial contamination in bag residues and its influence on in sacco measurements of forage nitrogen degradation in rumen, XVI International Congress, Nice, France, 4-11 October 1989, Vol. II, pp. 909-910.

[39] Nocek J.E., Grant A.L., Characterization of in situ nitrogen and fiber digestion and bacterial nitrogen contamination of hay crop forages preserved at different dry matter percentages, J. Anim. Sci. 64 (1987) 552-564.

[40] Noll F., L-lactate determination with LDH, GPT and NAD, in: Bermeyer H.U. (Ed.), Methods of Enzymatic Analysis, Vol. III, London, Academic Press, 1974, pp. 1475-1477.

[41] Ørskov E.R., Mc Donald I., The estimation of protein degradability in the rumen from incubation measurements weighted according to rate of passage, J. Agric. Sci. Camb. 92 (1979) 499-503.

[42] Papadopoulos Y.A., Mc Kersie B.D., A comparison of protein degradation during wilting and ensiling of six forage species, Can. J. Plant. Sci. 63 (1983) 903.

[43] Statistical Analysis Systems Institute Inc., SAS STAT Software, General Linear Model, SAS Institute, Cary, N.C., USA, 1985.

[44] Vérité R., Michalet-Doreau B., Chapoutot P. Peyraud J.L., Poncet C., Révision du système des Protéines Digestibles dans l'Intestin (PDI), Bull. Tech. CRZV Theix INRA 70 (1987) 19-34.

[45] Vik-Mo L., Degradability of forages in sacco. 2 Silages of grasses and red clover at two cutting times, with formic acid and without additive, Acta Agric. Scand. 39 (1989) 53-64.

[46] Wallace R.J., McKain A., comparison of methods for determining the concentration of extracellular peptides in rumen fluid of sheep, J. Agric. Sci. 114 (1990) 101-105.

[47] Warner A.C.L., Stacy B.D., The fate of water in the rumen. 2. Water balances throughout the feeding cycle in sheep, Br. J. Nutr. 22 (1968) $389-410$.

[48] Wilman D., Koocheki A., Lwoga A.B., Samaan S.F., Digestion in vitro of Italian and perennial ryegrass, red clover, white clover and lucerne, J. Br. Grassl. Soc. 72 (1977) 13-24.

[49] Willman D., Altimimi A.K., The in vitro digestibility and chemical composition of plant parts in white clover, red clover and lucerne during primary growth, J. Sci. Food Agric. 35 (1984) 133-138.

[50] Wilkins R.J., Jones R., Alternative home-grown protein sources for ruminants in the United Kingdom, Anim. Feed Sci. Technol. 85 (2000) 23-32. 